\title{
Agricultural exceptionalism at the state level: Characterization of wage and hour laws for U.S. farmworkers
}

\author{
Sarah O. Rodman, ${ }^{\mathrm{a}}$ * Colleen L. Barry, ${ }^{\mathrm{bc}}$ Megan L. Clayton, ${ }^{\mathrm{d}}$ \\ Shannon Frattaroli, ${ }^{b}$ Roni A. Neff, ${ }^{\text {be }}$ and Lainie Rutkow ${ }^{\text {bd }}$
}

Submitted June 8, 2015 / Revised November 6 and December 29, 2015 /

Published online February 22, 2016

Citation: Rodman, S. O., Barry, C. L., Clayton, M. L., Frattaroli, S. Neff, R. A., \& Rutkow, L. (2016).

Agricultural exceptionalism at the state level: Characterization of wage and hour laws for U.S.

farmworkers. Journal of Agriculture, Food Systems, and Community Development, 6(2), 89-110.

http://dx.doi.org/10.5304/jafscd.2016.062.013

Copyright (C) 2016 by New Leaf Associates, Inc.

\begin{abstract}
Despite difficult working conditions, farmworkers in the United States are excluded from many federal-level labor protections. The exclusion of farmworkers from standards that apply to most other workers is referred to as agricultural exceptionalism. This exclusion was born out of the successful efforts of southern agricultural interests to exempt black sharecroppers from the New Deal package of social reforms. Farmworkers continue
\end{abstract}

a Johns Hopkins Center for a Livable Future; 615 North Wolfe Street; Baltimore, Maryland 21205 USA.

b Department of Health Policy \& Management, Johns Hopkins Bloomberg School of Public Health; 624 North Broadway; Baltimore, Maryland 21205 USA.

c Department of Mental Health, Johns Hopkins Bloomberg School of Public Health; 624 North Broadway; Baltimore, Maryland 21205 USA.

d Department of Health, Behavior and Society, Johns Hopkins Bloomberg School of Public Health; 624 North Broadway; Baltimore, Maryland 21205 USA.

e Department of Environmental Health Sciences, Johns Hopkins Bloomberg School of Public Health; 615 North Wolfe Street; Baltimore, Maryland 21205 USA. to belong to particularly vulnerable social and economic groups. U.S. states can establish their own labor protections that go beyond federal laws and regulations. Though agricultural exceptionalism is understood at the federal level, little is known about agricultural exceptionalism in state labor standards. This study is a comprehensive 50state legal and regulatory mapping of minimum wage, overtime, and rest and meal period standards as they apply to farmworkers. To analyze the extent of agricultural exceptionalism in the states, we performed a search of iteratively defined search terms in WestLawNext. Two researchers

* Corresponding author: Sarah O. Rodman, MPH, PhD candidate, Johns Hopkins Center for a Livable Future; 1545 Sunset Boulevard; Los Angeles, California 90026 USA; +1-310-7296634; srodman2@jhu.edu

\section{Author Note}

Sarah O. Rodman, the primary author of this manuscript, was supported by a Johns Hopkins Center for a Livable FutureLerner Fellowship for the duration of the study. This study is part of her doctoral dissertation research. Portions of the findings of this study were presented orally at the annual meeting of the American Public Health Association, held in Chicago in November 2015. 
independently read and coded identified state laws and regulations in their entireties. Results reveal that agricultural exceptionalism is far-reaching in state-level minimum wage and overtime protections. Exceptionalism is universal in overtime standards. Rest and meal period standards exist less frequently at the state level, and exceptions for agriculture in those standards are rare. The results from this analysis are useful in identifying states and policy areas with strong and weak protections for farmworkers.

\section{Keywords}

agricultural exceptionalism, structural inequality, farmworkers, food policy, labor policy, federalism, legal mapping, minimum wage, overtime, United States

\section{Introduction}

Most farmworkers in the United States do notoriously demanding work, under trying conditions, for nearly unlivable compensation. Farm work is physically uncomfortable and exposes laborers to oftensevere weather conditions and hazardous materials (Getz, Brown, \& Shreck, 2008; United Farmworkers \& Bon Appetit Management Company Foundation, 2011; Villarejo et al., 2000). Rates of injury and infectious and chronic disease are high among farmworkers. Unstable housing, social isolation, and exploitative relationships with supervisors add to the stressful conditions they face (Getz et al., 2008; United Farmworkers \& Bon Appetit Management Company Foundation, 2011; Villarejo et al., 2000). Farmworkers usually do these arduous jobs for poverty-level wages (Robinson et al., 2011; Washington State Farmworker Housing Trust, 2008).

Given the conditions of farm labor, it is no surprise that this work has long been performed by those who are disenfranchised or outside dominant U.S. society. Farmworkers are drawn from shifting groups of people whose vulnerability falls along lines of race, ethnicity, and citizenship status (Gray,

\footnotetext{
${ }^{1}$ Growers and labor contractors can hire farmworkers directly or via guestworker programs (United Farmworkers \& Bon Appetit Management Company Foundation, 2011). Guestworker programs for temporary farmworkers provide
}

2013; Holmes, 2013). The history of U.S. farmworkers is that of populations that had few options other than agricultural work. Southern plantations relied on enslaved black people and then on mostly black sharecroppers (Farhang \& Katznelson, 2005; National Center for Farmworker Health, n.d.). Immigrants from various countries have been hired illegally and under various guestworker programs ${ }^{1}$ to meet the demand for those who were willing to do this difficult work (Martin, 2003; National Center for Farmworker Health, n.d.). Currently, farmworkers in the U.S. are largely undocumented workers from Mexico and Central America (Southern Poverty Law Center, 2013).

Over the last century, the U.S. government has created and expanded critical protections for workers. However, strides made in strengthening labor laws and regulations have consistently left farmworkers behind. We refer to the exclusion of farmworkers from standards that apply to most other workers as agricultural exceptionalism. Legal protections concerning minimum wage, overtime pay, unemployment insurance, collective organizing and bargaining, and occupational health all contain exceptions for farmworkers. The original exclusion of farmworkers from U.S. labor protections in the 1930s was driven by agricultural interests' desire to maintain the southern plantation economy that depended on the exploitation of black workers (Farhang \& Katznelson, 2005; Linder, 1986; Quadagno, 1995). The National Labor Relations Act of 1935 (NLRA), Social Security Act of 1935, and Fair Labor Standards Act of 1938 (FLSA) all excluded farmworkers from the population of workers given protections via these laws (Ngai, 2004). To this day, several of these exceptions still stand.

This paper investigates agricultural exceptionalism in wage and hour protections, including minimum wage, overtime, rest breaks and meal breaks, at the state level. U.S. states are permitted to create their own wage and hour protections so long as they meet or exceed those of the federal

agricultural employers in the U.S. a means of temporarily hiring non-immigrant foreign workers (U.S. Department of Labor, 2013a). When guestworkers' contracts are complete, they must return to their country of origin. 
government (United Farm Workers \& Bon Appetit Management Company Foundation, 2011). Employers must comply with the stronger of the two laws. Farmworker exceptions at the federal level have been well researched, but little is known about whether the 50 states have enacted increased wage and hour protections for farmworkers. While a 2010 summary exists of six state wage and hour laws as they pertain to farmworkers, a more comprehensive mapping of state laws and regulations offers an important tool for those interested in understanding and improving policy protections for farmworkers (United Farm Workers \& Bon Appetit Management Company Foundation, 2011).

This paper addresses the following questions: To what extent do state-level wage and hour protections go beyond federal standards to protect farmworkers? To what extent do those state protections also exempt farmworkers from coverage? In the literature review, we describe the history of agricultural exceptionalism in the U.S., the demographics of farm labor and the forces that influence those demographics, and the health challenges and poverty experienced by farmworkers. The literature review elucidates how agricultural exceptionalism is intertwined with maintenance of social inequalities that fall along lines of race, ethnicity, and citizenship. In the methods and results sections, we describe our comprehensive, 50-state legal mapping study that identifies variations in state wage and hour laws and regulations as they pertain to farmworkers. To conclude, we discuss the implications of the study results and how our findings can inform future study and action.

\section{Literature Review}

Historical Background of Agricultural Exceptionalism Prior to the 1930s, the U.S. did not have national social programs for minimum wage or overtime. The concept of social rights began to emerge after the Depression challenged the foundations of a "rugged individualism" (Quadagno, 1995). In 1938, the U.S. government established a federal

\footnotetext{
${ }^{2}$ While this analysis focuses on labor laws that affect farmworkers, the same laws apply in some states to a broader category of agricultural workers (e.g., livestock workers) at
}

minimum wage to stabilize the post-Depression economy and to create a standard of living that would protect the health and well-being of all U.S. workers ("The Minimum Wage: An Overview," n.d.). The federal minimum wage was established by the Fair Labor Standards Act (FLSA), part of the New Deal package of social reforms. The FLSA also contains standards for overtime pay (J. Grossman, 1978/n.d.). Overtime standards protect workers from the adverse societal and individual effects of excessive weekly work hours, including ill health and reduced time for parenting and leisure. The FLSA's overtime standards created, in theory, a monetary deterrent to employers overworking their employees (Golden, 1998). The FLSA did not contain standards for rest breaks or meal breaks and, to date, no federal law mandates lunch breaks or rest breaks for workers (U.S. Department of Labor [U.S. DOL], n.d.).

The sweeping social reforms of the New Deal explicitly excluded farmworkers. During the passage of the FLSA, southern Democrats held control over the most powerful seats in Congress. Those members were beholden to the interests of powerful agricultural employers in their states (Farhang \& Katznelson, 2005; Linder, 1986; Quadagno, 1995). If the FLSA did not have an exception for farmworkers, those employers stood to lose not only money, but an entire social and racial plantation system that had long benefitted them and had long rested on the exploitation of black workers. To protect the status quo, agricultural employers, via southern Congressional members, made sure there were exceptions for agriculture before the FLSA could pass (Farhang \& Katznelson, 2005; Linder, 1986; Quadagno, 1995). During FLSA debates, some southern members expressed concern that without an exception for farmworkers, wages between black and white laborers would be equalized (Farhang \& Katznelson, 2005).

The FLSA still contains explicit exceptions for farmworkers. ${ }^{2}$ Initially, all farmworkers were excluded from FLSA minimum wage protections,

both the state and federal level. States sometimes have differing definitions of what types of workers are considered 
but a 1966 amendment extended coverage to farmworkers on large farms (Linder, 1986). Farmworkers on small farms, however, are still exempted. ${ }^{3}$ Additional minimum-wage exceptions for farmworkers include workers who are family members of their employer; workers mainly involved in raising livestock; local workers harvesting crops by hand (hand harvesters) who commute from their permanent homes, are paid by the piece for crops harvested (piece-rate), and did not work in agriculture for 13 or more weeks in the preceding year; and nonlocal, piece-rate hand harvesters under 17 years old who work on the same farm as their parents (U.S. DOL, Wage and Hour Division, 2008a). Another agricultural exception in the FLSA is in the area of overtime protection. Farmworkers have no right to overtime pay under federal law.

\section{Farmworker Demographics}

During the passage of the New Deal, farmworkers in the South were mostly black and poor laborers who had been politically and economically disenfranchised and effectively stripped of citizenship rights (Gray, 2013). The New Deal provided subsidies to farmers that encouraged them to replace workers with machinery. Increased mechanization prompted the eviction of laborers, resulting in a large migration of black sharecroppers to northern cities (Quadagno, 1995). In the 1960s, public employment opportunities that were created through gains of the civil rights era incentivized further departure of black workers from agricultural labor (Gray, 2013).

On the West Coast over a century ago, immigrants replaced nearly all American-born farmworkers, who mostly abandoned agriculture's poor pay and working conditions for nonfarm jobs. Chinese immigrants who had been "imported" to build the Western railroad made up $75 \%$ of seasonal California farmworkers by the 1880 s (Martin, 2003). However, the Chinese Exclusion Act of 1882 barred further Chinese immigration,

agricultural workers.

3 The FLSA defines small farms as those that use less than 500

"man-days" of employee labor in any calendar quarter (i.e., three months) of the preceding year (U.S. DOL, 2008a). A

"man-day" is any 24-hour day in which a farmworker works at producing a need for another immigrant population to keep farm wages low (Martin, 2003). Chinese immigrants were replaced by Japanese immigrants, who were encouraged by the U.S. government to become farmworkers (London \& Anderson, 1970). By 1905 Japanese immigrants made up half of California's seasonal farm labor (Olmstead \& Rhode, 1997). Japanese farmworkers, however, were eventually successful at collectively organizing for higher wages. Farmers, therefore, had little objection when the U.S. engaged in an informal agreement with Japan to stop Japanese migration to the U.S. (Martin, 2003). In the 1940s, interned Japanese workers were used as farmworkers, as well as Italian and German prisoners of war (Martin, 2003). Farmworkers in the U.S. today are mainly immigrants from Mexico and Central America (Southern Poverty Law Center, 2013).

The North American Free Trade Agreement (NAFTA), implemented in 1994, required Mexico to allow subsidized food from the U.S. to enter the country while simultaneously eliminating Mexican farmers' subsidies. Mechanized, subsidized, and cheap corn from Canada and the U.S. flooded the Mexican market, and farmers there could not compete with the low prices of the imports (Fernández-Kelly \& Massey, 2007). Many Mexican farmers were dispossessed of their lands. At the same time, many low-wage assembly plant jobs were relocating from Mexico to even lower-wage regions like Southeast Asia and China. The resultant dearth of employment opportunities drove a massive increase in migration from Mexico to the United States (Fernández-Kelly \& Massey, 2007; Massey, Durand, \& Malone, 2002; Polaski, 2004). Many farmworkers in the U.S. today are former farmers who were dispossessed of their livelihoods by these and other international forces (Fernández-Kelly \& Massey, 2007).

The majority of farmworkers are not legally unauthorized to work in the U.S. One survey found that $46 \%$ of farmworkers hired by growers

least one hour, meaning 500 man-days translate to roughly seven full-time employees working five days a week, so a "small farm" has roughly seven or fewer full-time employees (United Farm Workers \& Bon Appetit Management Company Foundation, 2011). 
directly and $76 \%$ of those hired by farm labor contractors are undocumented (United Farmworkers \& Bon Appetit Management Company Foundation, 2011). Immigration status affects farmworkers' abilities to advocate for improvements in wages and working conditions. Employers have used immigration status to thwart farmworkers' attempts to unionize and advocate; organizing drives have been broken when employers threaten to call the Immigration and Naturalization Service (Haus, 2002). Among undocumented workers, the most recent immigrants to the U.S. are the least likely to organize (Moody, 2007).

In her 2013 book Labor and the Locavore, Margaret Gray argues that agricultural employers, with assistance from government agencies, have influenced the ethnic succession of farmworkers in order to ensure a workforce made up of the most vulnerable available populations. Gray (2013) shows that:

Agricultural employers have long deployed ethnic stereotypes to hasten demographic transitions in the work force. Incoming or preferred workers are praised for their strong work ethic, while outgoing workers are castigated as lazy and overly demanding. Racebased characterizations are vehicles for employers' rationalizations about who will be good workers. This kind of racial profiling, which is repeated whenever a new group is introduced, also intersects with employers' ceaseless search for quiescent workers to fill low-paying jobs. (p. 123)

In the late nineteenth century, farm owners called the Chinese ideal workers because they were perceived as not having the same aspirations as white workers and as being better suited to the harsh conditions than European laborers or white American laborers (Fuller, 1939). Farmers in the 1920s argued in official testimony to Congress that Mexican laborers were ideal farmworkers because they lacked the intelligence and skill to try to take on more supervisory, less backbreaking work (Tichenor, 2002). Farm owners and management continue to profile workers according to race and ethnicity. Gray (2013) explains that in the twentieth century black workers, who were gaining rights and opportunities, began to be seen as too demanding and "uppity." In her recent ethnographic work in New York state, Gray found that black workers were characterized by their employers as shiftless and abusive of drugs and alcohol. Puerto Ricans were thought of as lazy. American-born workers were seen as unreliable or unstable. Conversely, Mexicans and new undocumented workers were praised as loyal and having a strong work ethic (Gray, 2013). Marta Maria Maldonado's ethnographic work supports Gray's arguments. Maldonado shows that farm owners allude to the natural tendencies of "Hispanics" to do well in menial agricultural jobs and lack of desire to be bosses (Maldonado, 2009).

When groups of workers gain advantages through changes in citizenship status or other factors, even the most idealized groups can become undesirable (Gray, 2013). The perceived willingness of some laborers to work long hours without objection is unlikely a strong work ethic that falls along lines of race, ethnicity, or citizenship. More likely it represents the desperation of various groups to earn an income and support their families and a fear of retribution for making demands for improved wages or working conditions (Gray, 2013).

It is important to note that present-day farmworkers are not one undifferentiated group of "Latino" or "Hispanic" workers. Farmworkers come from diverse countries and cultural groups. There are categories of farmworkers delineated based on ethnicity and citizenship that determine how employers characterize them and what kinds of work they are assigned to perform. Generally, the more "indigenous" and the more Mexican a farmworker is perceived to be, the further down the ladder he or she is from a white U.S. citizen, and the more physically difficult and degrading his or her work tends to be (Holmes, 2013; Maldonado, 2009). Seth Holmes (2013) has documented this ethnic succession on U.S. farms. The most vulnerable populations perform the most undesirable jobs. As groups advance economically or socially, a more oppressed or vulnerable group replaces them. 
Government bodies at various levels facilitate employers' demographic preferences. Through exceptions to restrictive immigration policies and the creation of various guestworker programs, farmworker employers have been guaranteed an ample supply of cheap and disenfranchised labor. The Immigration Act of 1917 contained an exception to restrictive policies for those who were immigrating to do farm work, creating the first bracero (Mexican farmworker) program. In the midtwentieth century, a more formalized bracero contract labor program was initiated through a labor agreement between Mexico and the U.S. In order to facilitate this policy Congress had to remove a ban on contract labor that had existed since 1885 to stem the tide of immigrant workers (Ngai, 2014). The power of Congressional members from agricultural regions trumped evidence from the government that there was no farmworker shortage and other members' concerns about wages, labor standards, and allowing so many foreigners into the country (Ngai, 2014). After the notoriously abusive bracero program was dismantled, farmworkers could still be brought in on $\mathrm{H}-2 \mathrm{~A}$ visas (temporary visas to fill seasonal jobs). The H-2A visa program was initially advocated for by the Florida sugar cane industry in order to fulfill its demand for Caribbean workers to cut sugarcane (Southern Poverty Law Center, 2013). Today the $\mathrm{H}-2 \mathrm{~A}$ guestworker program is still the program under which farmworkers are brought to the U.S. for legal temporary employment.

Gray (2013) documents how the New York State Department of Labor (NYDOL) Rural Employment Program, which connects farmers with prospective workers, processes job opportunities in a way that bends to the demographic preferences of employers. Specifically, the hiring of domestic, mostly black, workers is minimized by the NYDOL through several hiring processes. Conversely, the department facilitates the hiring of Latino, foreign-born workers (Gray, 2013). In this case, the state aids growers in acquiring a labor force that is perceived to be less likely to demand higher wages or better working conditions.

\section{Farmworker Health and Poverty}

Employment conditions have a major effect on health and health inequalities via social, economic, and physical pathways; work can be considered a direct determinant of health disparities (Benach, Muntaner, \& Santana, 2007; Lipscomb, Loomis, McDonald, Argue, \& Wing, 2006). Farmworkers suffer myriad health consequences of their work. A 2013 report indicated that agriculture is the most hazardous industry for U.S. employees (National Safety Council, 2013). In 2011 agriculture was one of only two private industry sectors to see an increase in occupational injuries over the previous year; this increase was driven specifically by higher rates of injuries in crop production and animal production (U.S. DOL, Bureau of Labor Statistics, 2012).

Much farm labor entails spending many hours each day in uncomfortable physical positions, including performing repetitive motions that cause ergonomic injuries (Getz et al., 2008; United Farmworkers \& Bon Appetit Management Company Foundation, 2011; Villarejo et al., 2000). Farmworkers often do their work while exposed to extreme weather conditions that can cause heat stress, which sometimes leads to death. They often lack access to clean water or toilets. Many are also in contact with pesticides, herbicides, sulfur, and dust, and experience elevated risks of respiratory illnesses, skin conditions, cancer, eye and vision problems, and obesity-related chronic diseases. Rates of infectious diseases, including tuberculosis and parasites, are high among farmworkers (Getz et al., 2008; United Farmworkers \& Bon Appetit Management Company Foundation, 2011; Villarejo et al., 2000). In addition, farmworkers experience job and housing insecurity, isolated social conditions, and relationships with supervisors that can be exploitative or abusive (Getz et al., 2008). Despite their responsibility for the nation's food supply, farmworkers suffer from food insecurity at disproportionately high rates as compared to the rest of the U.S. (Minkoff-Zern, 2014a).

Many farmworkers work long enough hours that, in other industries, would grant them legal access to overtime pay. According to the most recent data available from the National Agricultural Workers Survey, $50 \%$ of farmworkers work over 40 hours per week. That statistic includes both workers hired directly by farm owners and those 
hired by intermediary labor contractors. A quarter of farmworkers work 50 hours per week or more (U.S. DOL, 2004).

Low income and unpaid income are major issues for U.S. farmworkers. Data from the National Agricultural Workers Survey (NAWS) shows that between 2005 and 2009, about half of farmworkers who had worked in the U.S. for an entire year or more made under US $\$ 20,000$ per year from all sources of income, including nonfarm employment (United Farmworkers \& Bon Appetit Management Company Foundation, 2011). A study in Washington state showed that in 2006, fewer than $7 \%$ of farmworkers in the state made more than US $\$ 20,000$ per year. The study reported that the average annual income of farmworkers in Washington state in 2006 was US\$12,327 (Washington State Farmworker Housing Trust, 2008). Minimum wage violations are common among farm employers. A 2011 study in North Carolina showed that $45.3 \%$ of farmworkers without $\mathrm{H}-2 \mathrm{~A}$ visas had experienced wage violations (Robinson et al., 2011). Income to a large degree determines the level of health care, shelter, nutrition, and transportation to which one has access. The ability to meet these basic needs has myriad effects on mental and physical health.

As the previous passages have established, farm work is often performed by the most marginalized groups of available workers. Social and structural inequalities suffered by these groups make them willing to do farm jobs. The health and economic consequences of this work are thereby a result of social inequalities, which fall along lines of race, ethnicity, and citizenship. Holmes (2013) calls the physically and emotionally injurious effects of social inequalities on farmworkers "structural violence." In his 2013 book, Fresh Fruit, Broken Bodies, Holmes elucidates structural violence by exploring the physical suffering of several farmworkers, including Abelino:

The social and political genesis of Abelino's knee pain could not have been clearer. His pain was caused unequivocally by the fact that he, as an undocumented Triqui man, had been excluded by both international market inequalities and local discriminatory practices from all but one narrow and particularly traumatic labor position. This occupation required him to bend over seven days a week, turning back and forth, in all kinds of weather, picking strawberries as fast as he possibly could. (Holmes, 2013, p. 94)

Agricultural exceptionalism in wage and hour protections, collective bargaining rights, and occupational health protections and enforcement creates lower standards for farm work than for most other forms of work in the U.S. In providing fewer protections for those who are already socially unequal, it contributes to structural violence against farmworkers and further entrenches social inequalities. In order to begin addressing this problem, it is important to fill gaps in our understanding of how agricultural exceptionalism operates in the U.S.

\section{Methods}

In this study, we aim to improve understanding of how farmworkers are excluded from wage and hour protections at the state level. We conducted a comprehensive search to identify state labor laws and regulations related to the following topics: (1) minimum wage; (2) overtime; (3) required rest periods; and (4) required meal periods. For all 50 states, and for each of these topics, we identified laws and regulations for the general population of workers, as well as for any exceptions or special laws for farmworkers. The Robert Wood Johnson Foundation's Public Health Law Research Program has developed best practice principles for the systematic identification, collection, and analysis of laws and regulations. These principles guided our approach to data collection and analysis (Anderson, Tremper, Thomas, \& Wagenaar, 2012).

\section{Data Collection}

To begin data collection, we defined a set of search terms based on the categories of law of interest. Initial search terms included "minimum wage," "maximum hours," "overtime pay," "rest period," and "meal period." We refined these search terms during early data collection through an iterative process, based on the language found in relevant laws and regulations. The final set of search terms included "minimum wage," "maximum hours," 
“overtime," "rest period," "rest\&period," "meal period" and "meal\&period."

We conducted searches using the above terms in WestLawNext between March and August 2014. This legal database allows researchers to search statutes and regulations for all 50 states. We ran searches within the statutory and administrative codes for each state. As a quality control measure we compared the identified state laws and regulations to publicly available materials created by the U.S. Department of Labor (U.S. DOL or DOL) (U.S. DOL, Wage and Hour Division, n.d.-b, n.d.-c, n.d.-d). The DOL materials contain information on general labor laws and regulations as they pertain to the majority of workers. These materials do not contain information specific to farmworkers. For the very few discrepancies that were identified between DOL materials and the laws and regulations searched, we consulted the text of the relevant law or regulation. These quality control measures were particularly important in confirming negatives (e.g., some states, such as South Carolina, did not have their own wage or hour laws) (U.S. DOL, Wage and Hour Division, n.d.-b). When states do not have their own wage or hour laws, they default to the federal standard (U.S. DOL, Wage and Hour Division, n.d.-b). When no statelevel law or regulation could be located, we verified its absence through secondary sources. As an additional quality control measure, we used publicly available information from the National Conference of State Legislatures to confirm whether new state labor laws had been enacted, but not yet documented in WestLawNext (National Conference of State Legislatures, 2014). For the three states that had enacted laws not yet in WestLawNext, we consulted the state legislature websites to obtain the full text of the newly enacted laws.

Because the search terms were designed to be broad, with the goal of capturing all relevant laws and regulations, the search at times retrieved hundreds or thousands of laws and regulations. We developed a set of exclusions to ensure that the final set of laws and regulations included only those relevant to the research question. For example, we applied exclusions to laws or regulations related to unemployment insurance, workers' compensation, and child labor. Though these exclusions apply to labor protections with degrees of agricultural exceptionalism, this analysis focuses on laws and regulations that affect the payment and working hours of adult, currently employed farmworkers. See Appendix A for a full list of exclusions.

For the relevant laws and regulations retrieved via WestLawNext, we captured the full text. A second researcher used the search protocol to independently capture laws and regulations for a randomly selected $10 \%$ subsample (i.e., five states). The findings of the two researchers were in agreement, save for one instance, which was resolved through discussion.

\section{Data Analysis}

We organized the laws and regulations we had identified in a spreadsheet, with a separate sheet for each of the following topics: minimum wage, overtime, rest periods, and meal periods. For each topic, the spreadsheet organized the data into four variables: continuous (e.g., dollar amount of state minimum wage), categorical (e.g. explicit, nonexplicit, or no exception for farmworkers), dichotomous (e.g., whether there is a state law or regulation), and qualitative (e.g., description of exceptions for farmworkers) variables. Within each topic, we organized results by state.

We read each law and regulation in its entirety. When coding for whether a law or regulation contained an exception for farmworkers, we used the following four categories:

- "N/A": no relevant law or regulation in general for the state.

- "N": a relevant law or regulation, but no exception was included for farmworkers.

- "Y": a relevant law or regulation that contained an explicit exception for farmworkers. Explicit exceptions could be made clear via a statement within the text of a law (e.g., clarifying that the law did not apply to employers in agriculture). Frequently, exceptions were found in a law's definition of "employee." States were coded as "Y" even when there are protections for farmworkers, if the protections were weaker than those for workers in general. 
- "NE" (non-explicit): a law or regulation that indirectly exempted all farmworkers or much of the agriculture industry. For instance, if a law or regulation applied only to specific sectors of workers (e.g., miners) that were not in agriculture, it was coded as "NE" because it excluded agriculture (along with other industries) by default. States were coded as "NE" if they referred to federal law.

A second researcher independently coded a randomly selected $10 \%$ subsample of laws and regulations (i.e., for five randomly selected states). The two researchers' coding matched for all but one variable for one state. That instance was clarified through discussion. ${ }^{4}$ Throughout both data collection and coding, we maintained a detailed research protocol.

\section{Results}

States vary widely in terms of their legislation and regulations for minimum wage, overtime, rest periods, and meal periods. The following 11 states have laws or regulations governing all four categories: California, Colorado, Illinois, Kentucky, Maine, Minnesota, Nevada, New Hampshire, Oregon, Vermont, and Washington. In contrast, the following four states have no laws or regulations for any of the four categories: Alabama, Louisiana, Mississippi, and South Carolina. Table 1 displays the states with and without their own labor standards in the categories of interest for this analysis.

Of the four categories examined, states most frequently have laws or regulations pertaining to minimum wage ( $n=45$ states) and overtime $(n=32$ states). Minimum wage and overtime are also the types of laws that most frequently contain explicit exceptions for farmworkers. Less than half of all U.S. states have laws or regulations pertaining to required meal periods for laborers, and less than one-quarter of states have standards pertaining to required rest periods. Table 2 shows the numbers and percentages of states that have their own standards with exceptions for farmworkers.

\section{Table 1. States With and Without Their Own Labor Standards, by Category of Standards}

\begin{tabular}{|c|c|c|}
\hline $\begin{array}{l}\text { Labor standard } \\
\text { category }\end{array}$ & States with own standards & States without own standards \\
\hline Minimum wage & All states other than those listed at right & $\begin{array}{l}\text { Alabama, Louisiana, Mississippi, South Carolina, } \\
\text { Tennessee }\end{array}$ \\
\hline Overtime & All states other than those listed at right & $\begin{array}{l}\text { Alabama, Arizona, Delaware, Florida, Georgia, } \\
\text { Idaho, Iowa, Louisiana, Mississippi, Nebraska, } \\
\text { Oklahoma, South Carolina, South Dakota, } \\
\text { Tennessee, Texas, Utah, Virginia, Wyoming }\end{array}$ \\
\hline Rest periods & $\begin{array}{l}\text { California, Colorado, Kentucky, Maine, Minnesota, } \\
\text { Nevada, Oregon, Pennsylvania, a Tennessee, } \\
\text { Vermont, Washington }\end{array}$ & All states other than those listed at left \\
\hline Meal periods & $\begin{array}{l}\text { California, Colorado, Connecticut, Delaware, } \\
\text { Illinois, Kentucky, Maine, Massachusetts, } \\
\text { Minnesota, Nebraska, Nevada, New Hampshire, } \\
\text { New York, North Dakota, Oregon, Pennsylvania, a } \\
\text { Rhode Island, Tennessee, Vermont Washington, } \\
\text { West Virginia }\end{array}$ & All states other than those listed at left \\
\hline
\end{tabular}

a Pennsylvania: The general population of workers in Pennsylvania do not have rest and meal period protections. These standards have an exception for female farmworkers, who are provided rest and meal period protections. Male farmworkers are not provided these protections.

4 Specifically, there was disagreement on whether or not Pennsylvania should be coded as having its own rest and meal period standards for the general population of workers, as the state only provides that protection to female workers. The coders resolved to consider the state as having those standards, but explained that particular outcome in the results section below via footnotes in the tables. 


\section{Minimum Wage}

The FLSA mandates that the workers it covers receive a minimum of US\$7.25 per hour (U.S. Department of Agriculture [USDA], 2009). When a state law specifies a different amount, employers must abide by the more generous of the two laws. Forty-five states have their own standards for minimum wage. The majority of those states establish minimum wages that either match $(n=18)$ or exceed $(n=19)$ the federal standard. Some states have minimum wage standards that differ based on the gross sales of businesses $(n=4)$, or on whether or not the business provides health insurance $(n=1)$. For the states whose laws or regulations establish a minimum wage lower than US\$7.25 per hour (i.e., Arkansas, Georgia, and Wyoming), the federal standard supersedes the state standard. (See Figure 1.) At the time of data collection, Washington had the highest state minimum wage

\section{Figure 1. Minimum Wage Agricultural Exceptions by State, U.S.}

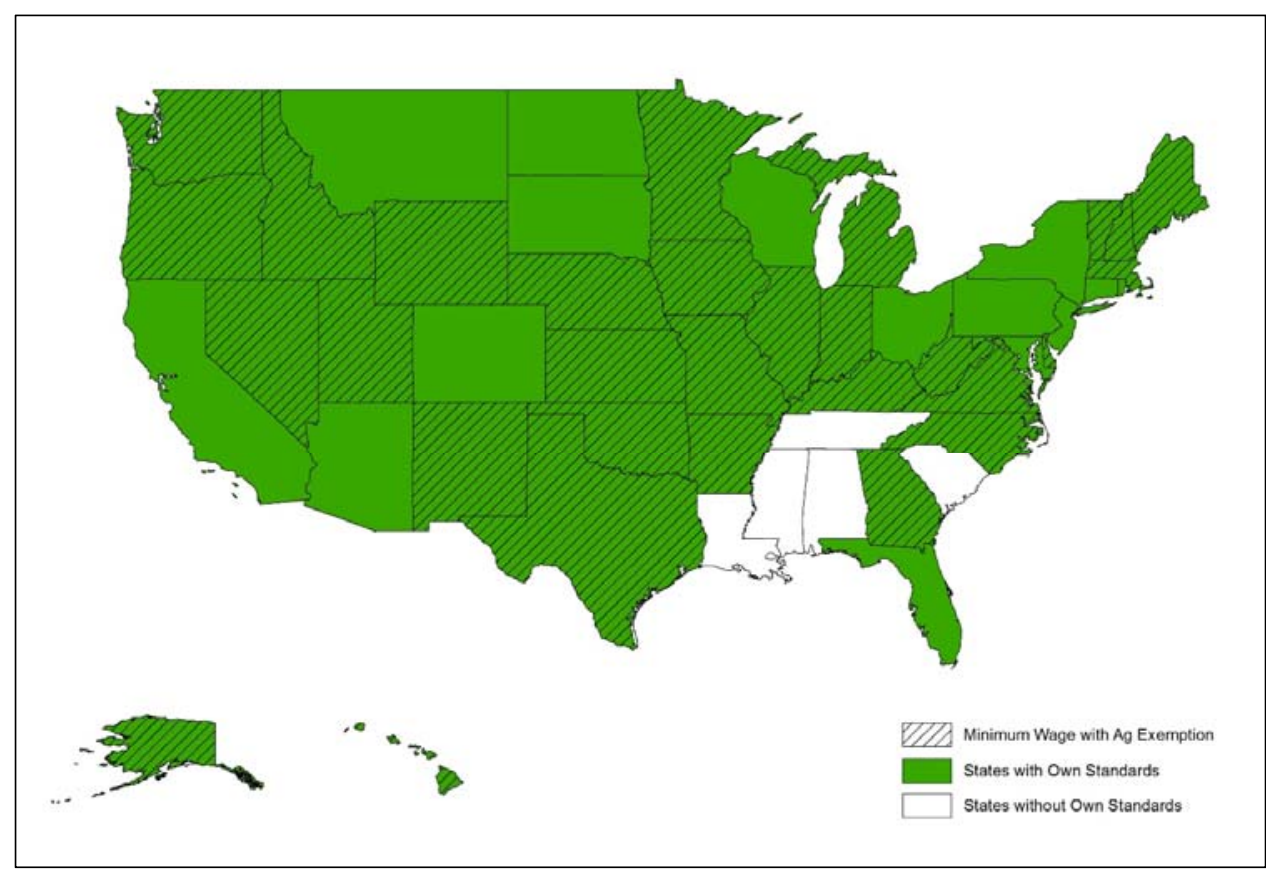

Image created by Johns Hopkins Center for a Livable Future.

Table 2. Number and Percentage of States with Their Own Labor Standards and Exceptions for Farmworkers

\begin{tabular}{lccc}
\hline $\begin{array}{l}\text { Labor standard } \\
\text { category }\end{array}$ & $\begin{array}{c}\text { States with own labor standards } \\
n \text { (\% of all 50 states) }\end{array}$ & $\begin{array}{c}\text { States with explicita exceptions } \\
\text { for some or all farmworkers } \\
n \text { (\% of states with standards) }\end{array}$ & $\begin{array}{c}\text { States with explicit or non- } \\
\text { explicit } \text { exceptions for some or }_{\text {all farmworkers }} \\
\text { Minimum wage }\end{array}$ \\
\hline Overtime & $32(90 \%)$ & $30(67 \%)$ & $34(76 \%)$ \\
\hline Rest periods & $11(22 \%)$ & $30(94 \%)$ & $32(100 \%)$ \\
\hline Meal periods & $21(42 \%)$ & $2(18 \%)$ & $3(27 \%)$ \\
\hline
\end{tabular}

a Exceptions were considered explicit if they were made clear via text in the body of the law or regulation (e.g., clarifying that the law did not apply to agriculture or excluding farmworkers from the definition of employee).

b Exceptions were considered non-explicit if a law or regulation indirectly included an exception for farmworkers (e.g., if a law or regulation applied only to a specific sector of workers [e.g., miners] that were not in agriculture). States were coded as non-explicit if they referred to definitions in federal law. 
preceding year, or individuals who are employed as hand-harvest laborers and paid on a piece-rate basis) (Ark. Admin. Code $\ 010.14 .1-106,2014$ ). For example, in Maine, employees exempt from the minimum wage law include "any individual employed in agriculture as defined in Maine Employment Security Law... except when that individual performs services for or on a farm with over 300,000 laying birds" (Maine Rev. Stat. Ann. $\$ 26.663(3)(\mathrm{A}), 2014)$.

Exceptions for farmworkers are also found frequently in the minimum wage laws' or regulations' definitions of terms. In many states' minimum wage laws, farmworkers are explicitly left out of the definition of "employee." States that exclude farmworkers from the definition of, and therefore the minimum wage rights given to, employees include Delaware, Hawaii, Indiana, Kansas,
Kentucky, Massachusetts, Minnesota, Nebraska, New Mexico, Ohio, Oklahoma, Vermont, Virginia, Washington, West Virginia, and Wyoming.

Three states have non-explicit exceptions for farmworkers in their minimum wage laws. Florida uses the FLSA's criteria for who is covered by minimum wage standards (Flor. Stat. Ann. \448.110(3), 2014). Arizona similarly does not cover employees exempted by the FLSA if they work at a small business grossing less than US $\$ 500,000$ in annual revenue (Ariz. Rev. Stat. \23.362(B), 2014; Ariz. Rev. Stat. \23.362(C), 2014). Colorado's Minimum Wage Order only applies to certain industry sectors (not including agriculture) and those covered by the FLSA (Colo. Code Regs. \ 7.1103-1:1, 2014).

Some states have minimum wage standards without exceptions for farmworkers that are equal

\section{Table 3. States with Their Own Labor Standards, With and Without Exceptions for Farmworkers, by Category of Standards}

\begin{tabular}{|c|c|c|c|}
\hline Labor standard category & With exceptions (explicit) & With exceptions (non-explicit) & Without exceptions \\
\hline Minimum wage & $\begin{array}{l}\text { Alaska, Arkansas, Delaware, Georgia, } \\
\text { Hawaii, Idaho, Illinois, Indiana, Iowa, } \\
\text { Kansas, Kentucky, Maine, Massachu- } \\
\text { setts, Michigan, Minnesota, Missouri, } \\
\text { Nebraska, Nevada, New Hampshire, } \\
\text { New Mexico, North Carolina, Okla- } \\
\text { homa, Oregon, Texas, Utah, Vermont, } \\
\text { Virginia, Washington, West Virginia, } \\
\text { Wyoming }\end{array}$ & Arizona, Colorado, Florida, Ohio & $\begin{array}{l}\text { California, Connecticut, Maryland, } \\
\text { Montana, New Jersey, New York, } \\
\text { North Dakota, Pennsylvania, Rhode } \\
\text { Island, South Dakota, Wisconsin }\end{array}$ \\
\hline Overtime & $\begin{array}{l}\text { Alaska, Arkansas, California, a } \\
\text { Connecticut, Hawaii, Illinois, Indiana, } \\
\text { Kansas, Kentucky, Maine, Maryland, } \\
\text { Massachusetts, Michigan, Minnesota, } \\
\text { Missouri, Montana, Nevada, New } \\
\text { Hampshire, New Jersey, New Mexico, } \\
\text { North Carolina, North Dakota, Ohio, } \\
\text { Oregon, Pennsylvania, Rhode Island, } \\
\text { Vermont, Washington, West Virginia, } \\
\text { Wisconsin }\end{array}$ & New York, Colorado & None \\
\hline Rest periods & Maine, Minnesota & Colorado & $\begin{array}{l}\text { California, Kentucky, Nevada, } \\
\text { Oregon, Pennsylvania,b Tennessee, } \\
\text { Vermont, Washington }\end{array}$ \\
\hline Meal periods & Maine, Minnesota & Colorado, Nebraska & $\begin{array}{l}\text { California, Connecticut, Delaware, } \\
\text { Illinois, Kentucky, Massachusetts, } \\
\text { Nevada, New Hampshire, New York, } \\
\text { North Dakota, Oregon, Pennsylvania, } \\
\text { Rhode Island, Tennessee, Vermont, } \\
\text { Washington, West Virginia c }\end{array}$ \\
\hline
\end{tabular}

a California and Maryland both have overtime protections for farmworkers, but they are lesser protections than those given to most workers. b In Pennsylvania, the rest and meal period protections for farmworkers stem from specific laws for that group, in addition to protections specifically for female workers, whereas the general population of male workers in Pennsylvania does not have rest or meal period protections. c Wisconsin gives migrant workers their own specific standards for meal periods, an exception over the general population of workers in the state. Wisconsin is not listed in this row because it does not provide a meal period standard for workers generally. 
to or greater than the federal standards. Those states are listed in Table 3 and shown in Figure 1, which shows all states that have their own labor standards relevant to this analysis and whether they have explicit, non-explicit, or no exceptions for farmworkers.

\section{Overtime}

Unless exempt, employees in the U.S. are entitled to overtime pay if they work more than 40 hours in any one workweek under the FLSA. The FLSA defines a workweek as seven consecutive 24-hour periods. For hours worked beyond 40 hours in one workweek, employees are entitled to overtime pay at a rate no less than time and one-half of their normal pay rate (U.S. DOL, Wage and Hour Division, n.d.-a). The FLSA exempts all farmworkers from overtime pay (U.S. DOL, 2008a).

As Table 3 and Figure 2 indicate, 32 states have their own standards for overtime pay. Every state with its own standard for overtime pay has an exception for farmworkers. Nearly all of them $(n=30)$ contain explicit exceptions for farmworkers. Colorado and New York have non-explicit exceptions; Colorado grants the right to overtime pay to specific industry sectors, of which agriculture is not included, while New York refers to federal law, which excludes farmworkers from overtime protections. California and Maryland both have overtime protections for farmworkers, but they are lesser protections than those given to most workers. In California, most workers are entitled to overtime if they work more than eight hours in one day or over 40 hours in one workweek (Calif. Code
Ann. \$510(a), 2014). Farmworkers in California, on the other hand, are entitled to overtime if they work over 10 hours in one day or more than six days in a workweek (Calif. Code Regs. \8 8.11140 (3)(A), 2014). Farmworkers who work seven consecutive days are entitled to overtime for all hours worked on the seventh day (Calif. Code Regs. S 8.11140(3)(A), 2014). Most Maryland workers are entitled to overtime pay after 40 hours of work in a week, whereas Maryland farmworkers are entitled after 60 hours of work in a week (Maryland Code Ann. \3-420(c), 2014; Maryland Code. Ann. \3415(a), 2014.).

As with state standards for minimum wage, some states create an explicit exception for overtime pay for farmworkers by leaving the whole agriculture industry out of the definition of employee. States that exclude farmworkers from the definition of employee as it pertains to overtime pay are Indiana, Kansas, Kentucky, Minnesota, Maine, New Mexico, Vermont, West Virginia and Washington. The majority of these exceptions are written clearly into the laws. For example, Illinois' overtime standards are not applicable to "any employer of agricultural labor, with respect to
Figure 2. Overtime Agricultural Exceptions by State, U.S.

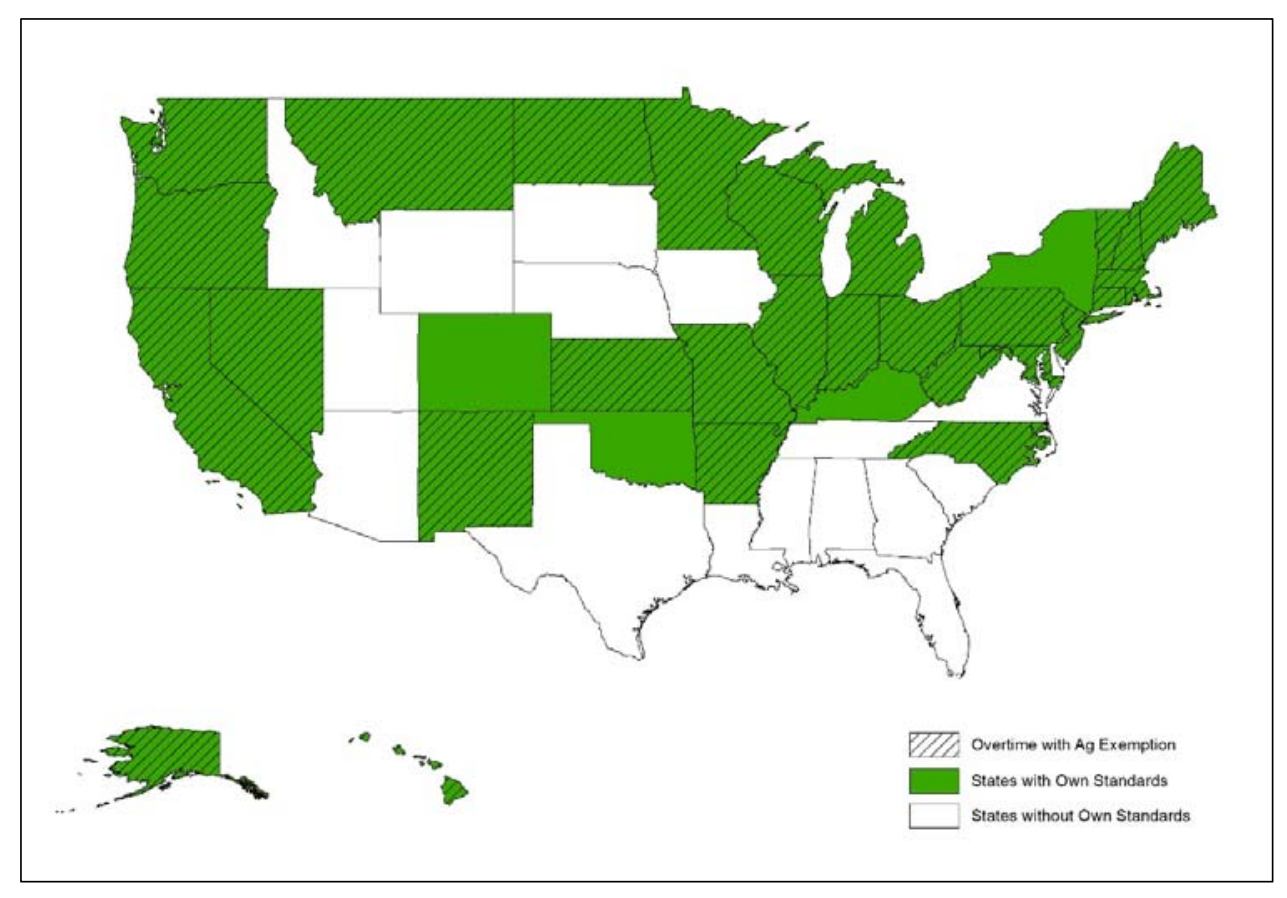

Image created by Johns Hopkins Center for a Livable Future. 
agricultural employment" (Ill. Comp. Stat. Ann. \820.105/4a.(2)(C), 2014).

\section{Rest Periods}

Federal law does not require that employers give employees rest or meal periods. However, when employers do offer break periods between five and 20 minutes, federal law requires those breaks to be compensable time (U.S. DOL, n.d.).

A minority of states $(n=11)$ have official standards for rest periods. In six states (California, Colorado, Kentucky, Nevada, Oregon and Washington), for every four consecutive hours of work, laborers must be given 10 minutes of paid rest time. Maine and Minnesota have explicit exceptions for farmworkers in their rest period standards (Maine Rev. Stat. Ann. \26.663(3)(A), 2014; Maine Rev. Stat. Ann. \26.601, 2014; Minn. Stat. Ann. \177.23(7)(1-3), 2014; Minn. Stat. Ann. \177.253 (1), 2014). (See Figure 3 and Table 3.)

Pennsylvania's standards for rest periods are anomalous, as there is a standard only for female laborers, in that they cannot legally work more than five consecutive hours without a rest period (Penn. Stat. \43.107, 2014). In general, male laborers are

Figure 3. Rest Period Agricultural Exceptions by State, U.S.

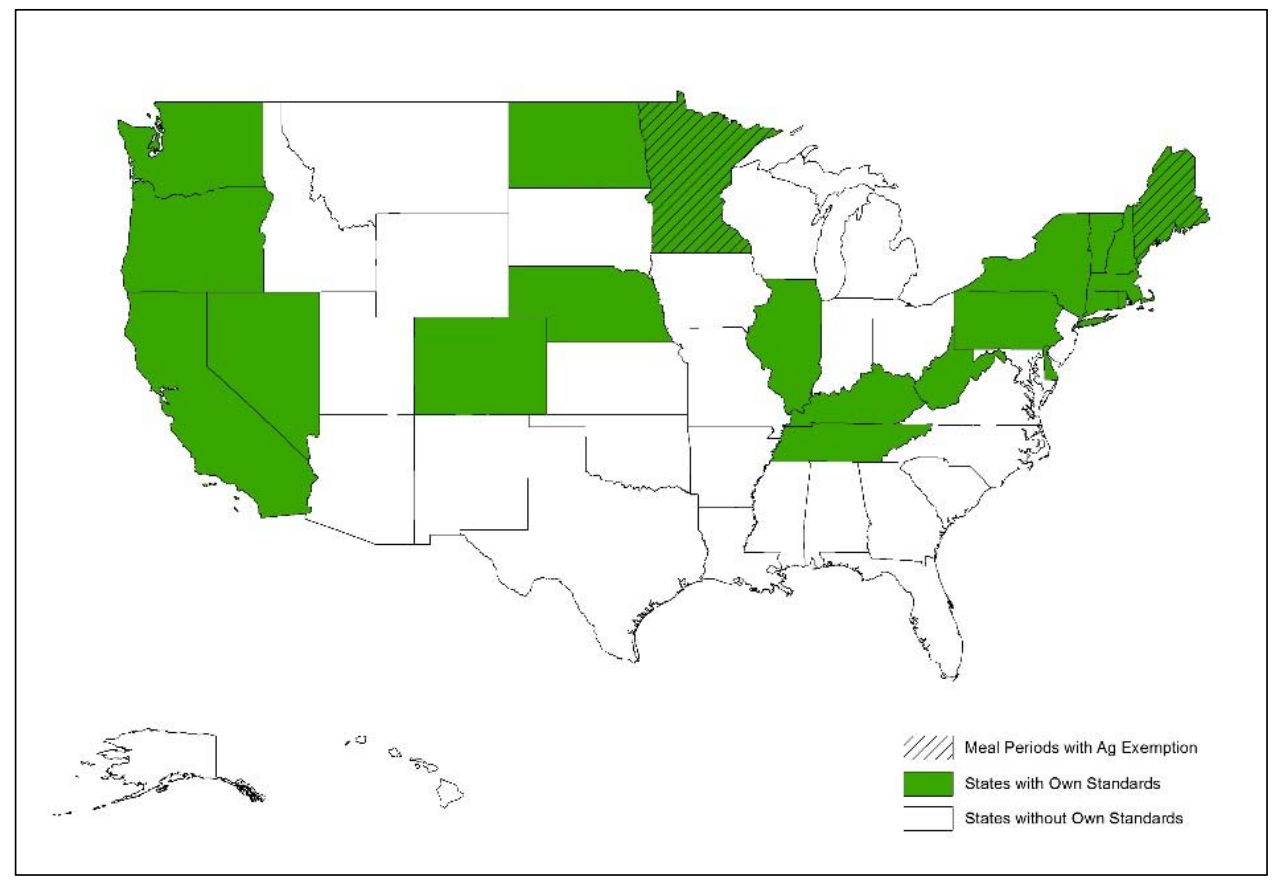

Image created by Johns Hopkins Center for a Livable Future. not entitled to a rest period in Pennsylvania. However, Pennsylvania has the same standard for seasonal farmworkers, regardless of gender, as it does for women (Penn. Stat. \43.1301.207(c), 2014). In the case of Pennsylvania's rest period standards, female farmworkers appear to have a favorable exception compared to male laborers in general.

\section{Meal Periods}

Meal periods of 30 minutes or more are not required to be compensable under federal law (U.S. DOL, n.d.). Twenty-one states have standards for meal periods (see Figure 3). In most cases, employees are entitled to a 30-minute unpaid meal period for some number of consecutive hours worked. Maine and Minnesota have explicit exceptions for farmworkers in their meal period standards (Maine Rev. Stat. Ann. \$ 26.663 (3)(A), 2014; Maine Rev. Stat. Ann. \26.601, 2014; Minn. Stat. Ann. \ $177.23(7)(1-3), 2014 ;$ Minn. Stat. Ann. \ 177.254 (1), 2014).

For meal period standards, Pennsylvania and Wisconsin stand out. Pennsylvania's meal period standards apply to the same workers as do the standards for rest periods, described above. While

Wisconsin has no strict standards for meal periods for the general population of workers (meal periods are merely recommended), migrant workers are entitled to an unpaid period of at least 30 minutes for more than six hours of consecutive work (Wisc. Ann. Stat. \103.935(2), 2014).

Several states with meal period standards have exceptions for employers with a small number of employees. States with such exceptions 
include Connecticut, Delaware, Nevada, and Rhode Island (Conn. Gen. Stats. Ann. \31-51ii(c)(3), 2014; Del. Code Ann. \19.707(a)(3), 2014; Nev. Rev. Stats. Ann. \608.019 (3)(a), 2014; Rhode Island Gen. Laws \28-3-14(b), 2014). While these exceptions may include many farms, this type of exception for small businesses was not counted as an agricultural exception.

\section{Discussion}

Laws and regulations for working conditions and labor standards - including minimum wage, overtime pay, and rest and meal periods - exist to minimize occupational hazards and to establish compensation that is sufficient to meet workers' basic economic needs (Bhatia, Gaydos, Yu, \& Weintraub, 2013). Though several of these basic labor protections have been societally recognized as important through federal codification, many exclude farmworkers from coverage. The original exceptions for farmworkers in U.S. labor law were grounded in agricultural employers' attachment to a system that economically disadvantaged non-white farmworkers (Linder, 1986). Today, most farm owners are still white, while most farmworkers are still people of color. The USDA reports that according to the 2012 Census of Agriculture, although the diversity of farm operators is growing, the primary operators of $96 \%$ of farms in the U.S. are white (USDA, 2014). Over the past several centuries, the racial composition of farmworkers has gone from being mostly black to mostly foreign-born Latino workers (Linder, 1986; United Farm Workers \& Bon Appetit Management Company Foundation, 2011).

Our analysis shows that agricultural exceptionalism at the state level is far-reaching. Many states have established labor protections that are equal to or more rigorous than the minimum standards set by the federal government. In the areas of minimum wage and overtime, most of these state laws and regulations have exceptions for farmworkers that look much like the federal exceptions. Over two-thirds of the 45 states with their own minimum wage standards exclude some farmworkers from protection. Every state with its own overtime standard has an exception for farmworkers. The adverse health effects of long work hours and low pay are a concern. Given the long hours worked by many farmworkers, overtime protection is an important area for future legislative and regulatory efforts and for public health advocacy.

State standards in the areas of meal and rest breaks were less common than for minimum wage and overtime, as were exceptions in those areas. Less than half of states have meal period requirements, and less than one-quarter of the states have rest period requirements. A minority of state meal and rest period requirements have exceptions for farmworkers.

Several factors determine whether states enact 
policies that go beyond standards set by the federal government. States' policy priorities are determined by myriad internal characteristics, including citizen demands, interest group demands, the political ideology of elected and appointed officials, and a state's resources and obstacles that can support or hinder the policy (Whitaker, Herian, Larimer, \& Lang, 2012). Legislators in states with dominant economic interests such as agriculture or organized labor tend to protect those interests (Hamm \& Moncrief, 2012).

The history of agricultural exceptionalism reveals the strong power of grower interests to influence legislation affecting farmworkers (Farhang \& Katznelson, 2005; Linder, 1986; Quadagno, 1995). Interest groups continue to be influential in the areas of agriculture and labor policy in the twenty-first century (M. Grossmann, 2012): U.S. agribusiness has contributed financial resources to politicians and political parties at the federal level. For instance, in the 2012 election cycle, agribusiness contributed over US $\$ 92$ million, mostly to Republicans (Center for Responsive Politics, 2013a). Crop producers contributed nearly US $\$ 29$ million of that total (Center for Responsive Politics, 2013b). Growers, including organic growers, have successfully opposed labor legislation at the state level, including minimum wage standards and workplace health and safety standards (Getz et al., 2008).

Of the laws and regulations of interest in this analysis, those that place the greatest economic demand on employers tended to have the highest rate of exceptions for farmworkers. The ubiquitous exceptions for farmworkers in overtime may be due to the increased economic demand that overtime requirements place on employers. Minimum wage laws set a standard that overtime protections build on, by requiring more pay for more work. Agricultural employers have a strong incentive to fight state policies that would interfere with federal overtime exemptions for their employees. In the same vein, the relative lack of exceptions in meal period requirements may be attributed to the lack of economic burden on employers and farms created by these protections. Meal periods are generally unpaid nonwork time and, therefore, agricultural interest groups have relatively little motivation to lobby against such protections.

Rest periods are nonwork time that an employer must generally pay for, which makes the relatively low rate of exceptions for farmworkers in this area stand out. Only two of the 11 states with rest period standards have explicit exceptions for farmworkers. This result may be because many of the farmworkers in states with rest period standards are paid on a piece-rate basis, not hourly. Under piece-rate payment, a worker is rewarded for the volume of crops picked, rather than the number of hours worked. This system incentivizes workers to skip rest periods (Cornish, 2015; Gallant, 2015). Agricultural employers thus have had little incentive to fight for exceptions to rest period standards. However, in July 2015 Washington state's supreme court ruled that piece-rate farmworkers must be paid separately for their rest periods at a rate not lower than what they are making when they are working (Rowe, 2015). This ruling may open the door to similar rulings in other agriculture-oriented states with rest period standards and no exceptions for farmworkers (Cornish, 2015).

California and New York have had vibrant farmworker organizing movements in recent decades that have won legislative victories in farmworker protections (Gray, 2013; Martin, 2003). The strength of farmworker interest groups may explain why these states stand out as having fewer exceptions for farmworkers than most other states. For the four labor protections included in this analysis, California, New York, Pennsylvania, and Wisconsin have relatively strong protections for farmworkers. California has its own protections for minimum wage, overtime, and rest and meal periods, with exceptions for farmworkers only for overtime. New York has standards for minimum wage, overtime, and meal periods, with no exceptions for farmworkers for minimum wage or meal period standards. California, New York, Pennsylvania, and Wisconsin could serve as case studies to understand why and how these states have become good examples for protecting laborers in agriculture.

The states with no standards for any of the examined labor protections share some similarities that may merit further exploration. For instance, as 
of early 2015 they are all southern states with Republican governors, House, and Senate majorities (The Henry J. Kaiser Family Foundation, 2015). These characteristics and perhaps other similarities in these states may contribute to their lack of labor protections. The strength of the Republican party in these states may, for instance, contribute to legislatures' relative lack of support for labor issues. Democrats generally have a more favorable view of the interests of organized labor than do Republicans (Newport \& Saad, 2011). The South's particular history of labor and politics, explored earlier in this paper, may also contribute to these similarities.

States that have several of their own labor standards and also several exceptions may present opportunities for advocates, in that labor protections have already been codified; removing a farmworker exception may prove easier than passing new labor laws entirely. On the other hand, these states may face powerful influences from agricultural employers or a lack of organized farmworker interest groups, which may explain why they have exceptions for farmworkers for every protection. The same two states with exceptions for farmworkers in meal period standards, Maine and Minnesota, have exceptions in rest period standards. Maine and Minnesota may therefore serve as interesting case studies as states that have gone farther than most other states in codifying agricultural exceptionalism in their labor protections and why that may be.

Lack of citizenship and documentation make it difficult for farmworkers today to become priorities for policymakers who could remedy agricultural exceptionalism. Agricultural employers outweigh farmworkers in economic resources and in their rights to vote or organize (Delgado, 1993; Haus, 2002; Kammer, 2009; Moody, 2007). Under federal law, a farmworker can be fired for joining a labor union (National Labor Relations Board, n.d.).

\footnotetext{
${ }^{5}$ Despite challenges to organizing for improved labor rights and conditions, there have been notable successes among farmworkers. The United Farm Workers and other farmworker unions have gained successes in collective bargaining legislation and improved grower contracts (United Farm Workers, n.d.). In more recent years, the Coalition of
}

States can go above the federal NLRA, which sets a policy floor, but only California does so (Agricultural Labor Relations Board, 2013; United Farmworkers \& Bon Appetit Management Company Foundation, 2011). Data from the most recent 10 years of the National Agricultural Workers Survey showed that only one percent of farmworkers have worked under a union contract in the previous two years (United Farmworkers \& Bon Appetit Management Company Foundation, 2011). Even farmworkers with collective bargaining rights may be fearful of organizing because of their lack of citizenship status (Haus, 2002). ${ }^{5}$

The growing alternative food movement has the potential to serve as a strong ally to labor in improving farmworker conditions (Sbicca, 2015). However, the movement has historically been more focused on environmental sustainability and increasing consumption of good food than on labor issues and economic justice (Myers \& Sbicca, 2015). Despite evidence that limited income is a critical barrier to consumption of certain foods, many alternative food movement projects that aim to improve diets do so via education or by increasing availability of good food (Minkoff-Zern, 2014b; Myers \& Sbicca, 2015). Trends in the alternative food movement indicate that the movement tends toward white and upper-middle-class biases, which often exclude the voices and visions of food workers (Sbicca, 2015). In order to better the lives of communities facing poverty and diet-related diseases and to improve their purchasing power, distribution of wealth must be addressed (Myers \& Sbicca, 2015). The unlivable wages earned by farmworkers and other food workers should be key targets for movements concerned with food justice and food sovereignty (Minkoff-Zern, 2014a). Some groups working on improved conditions for food workers understand that fighting racism is critical to ending economic inequality (Sbicca, 2015). Increased cross-movement alliances between labor

Immokalee Workers (CIW) has drawn attention to the poor conditions of farmworkers in the Southeastern U.S. via collective organizing, strikes and boycotts. CIW's efforts have accomplished several wins in raising wages and improving conditions for the farmworkers involved (Coalition of Immokalee Workers, 2012). 
and the alternative food movement are now growing and have the potential to improve the lives of workers in agriculture and other areas of the food system. Addressing the state-level agricultural exceptionalism that is revealed by this study should be one such effort toward strengthening structural protections for farmworkers.

\section{Limitations}

The search process for this study was comprehensively implemented in accordance with best practices for legal mapping studies. However, it is possible that some relevant laws and regulations were unintentionally excluded in the search process. This analysis does not consider the extent to which the laws and regulations identified are enforced. For those farms that are legally required to provide the labor protections examined in this analysis, how many are in compliance is not known. Record-keeping of regulatory enforcement is poor at the federal and state levels, and monitoring efforts lack transparency and traceability (United Farm Workers \& Bon Appetit Management Company Foundation, 2011).

Finally, based on the results of this analysis, it is difficult to quantify the full reach of agricultural exceptionalism in U.S. labor policies. Although the U.S. DOL defines small farms in terms of "mandays," public data sources do not measure labor or farm size in this way (United Farm Workers \& Bon Appetit Management Company Foundation, 2011). The incongruence of how farm size and labor are measured makes it challenging to understand the true impact of exceptions for agricultural labor. The exact number of farms and farmworkers that are not under state and federal labor protections remains unclear. However, based on this analysis, it is still evident that the number of farmworkers affected by exceptionalism is significant.

\section{Future Research}

Due to the general paucity of data related to farmworkers in the U.S., there is a need for future research in several areas. More systematic legal research is needed regarding other types of farmworker protections. Understanding the statelevel legal and regulatory landscape for farmworkers in the U.S. is an important first step in identifying protective laws and areas to target future efforts. Case studies and legislative histories of states with both strong and weak protections can help identify best political strategies and important pitfalls in making legal progress. Future studies that investigate these protections in terms of the states' social conditions at the time of enactment or promulgation would be particularly helpful in revealing variables that have led to agricultural exceptionalism at the state level.

\section{Conclusion}

Labor protections have been enacted at the federal and state levels in the U.S. to ensure a standard of living and working for laborers. However, since the enactment of several of those protections, farmworkers have been given categorically fewer rights than workers in other industries. Farmworkers have been excluded from federal protections considered basic and crucial in the U.S. for nearly a century. This analysis reveals that many states also fail to give farmworkers the protections granted to most other laborers, especially with regards to overtime and minimum wages. This state-level agricultural exceptionalism perpetuates the historical pattern of farm work being performed by only the most marginalized populations of available workers. The information in this study may be used to support future efforts at strengthening protections for farmworkers, in terms of helping both to identify specific states' model policies and geographic priorities for intervention.

\section{References}

Agricultural Labor Relations Board. (2013). Agricultural Labor Relations Board. Retrieved January 28, 2013, from http://www.alrb.ca.gov/

Anderson, E., Tremper, C., Thomas, S., \& Wagenaar, A. C. (2012). Measuring statutory law and regulations for empirical research: A methods monograph. Philadelphia: Public Health Law Research Program, Temple University. Retrieved from http://publichealthlaw research.org/sites/default/files/downloads/resourc e/MeasuringLawRegulationsforEmpiricalResearchMonograph-AndersonTremper-March2012.pdf

Ariz. Rev. Stat. \$ 23.362(B) (2014).

Ariz. Rev. Stat. \ 23.362(C) (2014).

Ark. Admin. Code \ 010.14.1-106 (2014). 
Benach, J., Muntaner, C., \& Santana, V. (Chairs). (2007). Employment conditions and health inequalities: Final report to the WHO. Geneva: Employment Conditions Knowledge Network, World Health Organization. Retrieved from http://www.who.int/social determ inants/resources/articles/emconet who report.pdf

Bhatia, R., Gaydos, M., Yu, K., \& Weintraub, J. (2013). Protecting labor rights: Roles for public health. Public Health Reports, 128(Suppl. 3), 39-47. Retrieved from http://www.pubmedcentral.nih.gov/article render.fcgi? artid $=3945448 \&$ tool $=$ pmcentre $z \&$ rende rtype $=$ abstract

Calif. Code Ann. S 510(a) (2014).

Calif. Code Regs. S 8.11140(3)(A) (2014).

Center for Responsive Politics. (2013a). Agribusiness: Top contributors to federal candidates, parties, and outside groups. Retrieved August 13, 2013, from OpenSecrets.org website: http://www.opensecrets. org/industries / contrib.php?ind $=$ A\&cycle $=2012$

Center for Responsive Politics. (2013b). Crop production \& basic processing: Top contributors to federal candidates, parties, and outside groups. Retrieved August 13, 2013, from OpenSecrets.org website: http://www.opensecrets.org/industries/ contrib.php?ind $=\mathrm{A} 01$

Coalition of Immokalee Workers. (2012). About CIW. Retrieved July 30, 2013, from http://ciwonline.org/about/

Colo. Code Regs. \ 7.1103-1:1 (2014).

Conn. Gen. Stats. Ann. \31-51ii(c)(3) (2014).

Cornish, A. (2015, April 15). Washington Supreme Court to review changes to farm worker rest breaks [Radio broadcast]. National Public Radio. Retrieved from http://www.npr.org/2015/04/15/399937 686/washington-supreme-court-to-review-changesto-farm-worker-rest-breaks

Del. Code Ann. \19.707(a)(3) (2014).

Delgado, H. L. (1993). New immigrants, old unions: Organizing undocumented workers in Los Angeles. Philadelphia: Temple University Press.

Farhang, S., \& Katznelson, I. (2005). The southern imposition: Congress and labor in the New Deal and Fair Deal. Studies in American Political Development, 19(1), 1-30. http://dx.doi.org/10.1017/S0898588X05000015

Fernández-Kelly, P., \& Massey, D. S. (2007). Borders for whom? The role of NAFTA in Mexico-U.S. migration. The Annals of the American Academy of Political and Social Science, 610(1), 98-118. http://dx.doi.org/10.1177/0002716206297449

Flor. Stat. Ann. \448.110(3) (2014).

Fuller, L. V. (1939). The supply of agricultural labor as a factor in the evolution of farm organization in California (Unpublished doctoral dissertation). University of California, Berkeley.

Gallant, A. (2015, August 3). Beat the heat: How workers survive brutal farm summers. Modern Farmer. Retrieved from http://modernfarmer. com/2015/08/farmworkers-survive-heat-stress/

Getz, C., Brown, S., \& Shreck, A. (2008). Class politics and agricultural exceptionalism in California's organic agriculture movement. Politics \& Society, 36(4), 478-507. http://dx.doi.org/10.1177/0032329208324709

Golden, L. (1998). Working time and the impact of policy institutions: Reforming the overtime hours law and regulation. Review of Social Economy, 56(4), 522-541. http://dx.doi.org/10.1080/00346769800000048

Gray, M. (2013). Labor and the locavore: The making of a comprehensive food ethic. Berkeley: University of California Press.

Grossman, J. (1978/n.d.). Fair Labor Standards Act of 1938: Maximum struggle for a minimum wage. Retrieved December 4, 2014, from http://www.dol.gov/dol/aboutdol/history/ flsa1938.htm

Grossmann, M. (2012). Interest group influence on US policy change: An assessment based on policy history. Interest Groups \& Advocacy, 1(2), 171-192. http://dx.doi.org/10.1057/iga.2012.9

Hamm, K., \& Moncrief, G. (2012). Legislative politics in the states. In V. Gray, R. L. Hanson, \& T. Kousser (Eds.), Politics in the American states: A comparative analysis (10th ed.) (pp. 163-207). London, England: Sage Publications.

Haus, L. A. (2002). Unions, immigration, and internationalization: New challenges and changing coalitions in the United States and France. New York: Palgrave Macmillan.

Henry J. Kaiser Family Foundation, The. (2015). State political parties [Table]. Retrieved February 18, 2015, from http://kff.org/other/state-indicator/statepolitical-parties / 
Holmes, S. M. (2013). Fresh fruit, broken bodies: Migrant farmworkers in the United States. Berkeley: University of California Press.

Ill. Comp. Stat. Ann. S 820.105/4a.(2)(C) (2014).

Kammer, J. (2009). Immigration raids at Smithfield:

How an ICE enforcement action boosted union organizing and the employment of American workers. Retrieved March 5, 2012, from the Center for Immigration Studies website: http://cis.org/SmithfieldImmigrationRaidUnionization

Linder, M. (1986). Farm workers and the Fair Labor Standards Act: Racial discrimination in the New Deal. Texas Law Review, 65, 1335-1393. Retrieved from http: / / papers.ssrn.com/abstract $=2205898$

Lipscomb, H. J., Loomis, D., McDonald, M. A., Argue, R. A., \& Wing, S. (2006). A conceptual model of work and health disparities in the United States. International Journal of Health Services, 36(1), 25-50. http://dx.doi.org/10.2190/BRED-NRJ7-3LV7$\underline{\text { QQCG }}$

London, J., \& Anderson, H. (1970). So shall ye reap. New York: Thomas Y. Crowell Company.

Maine Rev. Stat. Ann. \ 26.601 (2014).

Maine Rev. Stat. Ann. \ 26.663(3)(A) (2014).

Maldonado, M. M. (2009). 'It is their nature to do menial labour': The racialization of 'Latino/a workers' by agricultural employers. Ethnic and Racial Studies, 32(6), 1017-1036. http://dx.doi.org/10.1080/01419870902802254

Martin, P. L. (2003). Promise unfulfilled: Unions, immigration, and the farm workers. Ithaca, New York: Cornell University Press.

Maryland Code Ann. \3-415(a) (2014).

Maryland Code Ann. S 3-420(c) (2014).

Massey, D. S., Durand, J., \& Malone, N. J. (2002). Beyond smoke and mirrors: Mexican immigration in an era of economic integration. New York: Russell Sage Foundation.

Minimum wage. (n.d.). In Wex Legal Dictionary. Retrieved from http://www.law.cornell.edu/wex/ minimum wage

Minkoff-Zern, L.-A. (2014a). Hunger amidst plenty: Farmworker food insecurity and coping strategies in California. Local Environment, 19(2), 204-219. http://dx.doi.org/10.1080/13549839.2012.729568
Minkoff-Zern, L.-A. (2014b). Knowing "good food": Immigrant knowledge and the racial politics of farmworker food insecurity. Antipode, 46(5), 11901204. http://dx.doi.org/10.1111/j.14678330.2012.01016.x

Minn. Stat. Ann. \177.23(7)(1-3) (2014).

Minn. Stat. Ann. \ 177.253(1) (2014).

Minn. Stat. Ann. \177.254(1) (2014).

Moody, K. (2007). US labor in trouble and transition: The failure of reform from above, the promise of revival from below. New York: Verso Books.

Myers, J. S., \& Sbicca, J. (2015). Bridging good food and good jobs: From secession to confrontation within alternative food movement politics. Geoforum, 61, 17-26. http://dx.doi.org/10.1016/i.geoforum.2015.02.003

National Center for Farmworker Health. (n.d.). About America's farmworkers. Retrieved July 24, 2013; archived at http://web.archive.org/web/20130731 050947/http://www.ncfh.org/?pid=4\&page=2

National Conference of State Legislatures. (2014). State minimum wages | 2014 minimum wage by state.

Retrieved November 10, 2014, from http://www.ncsl.org/research/labor-andemployment/state-minimum-wage-chart.aspx

National Labor Relations Board. (n.d.). National Labor Relations Act. Retrieved July 29, 2013, from http://www.nlrb.gov/national-labor-relations-act

National Safety Council. (2013). Injury facts, 2013 edition. Retrieved from http://www.mhi.org/downloads/ industrygroups/ease/technicalpapers/2013National-Safety-Council-Injury-Facts.pdf

Nev. Rev. Stats. Ann. \608.019(3)(a) (2014).

Newport, F., \& Saad, L. (2011, March 11). Republicans negative, Democrats positive in describing unions. Retrieved from http://www.gallup.com/poll/ 146588/republicans-negative-democrats-positivedescribing-unions.aspx

Ngai, M. M. (2014). Impossible subjects: Illegal aliens and the making of modern America. Princeton, New Jersey: Princeton University Press.

Olmstead, A., \& Rhode, P. (1997). An overview of the history of California agriculture. In J. Siebert (Ed.), California agriculture: Issues and challenges (pp. 1-27). Berkeley, California: Giannini Foundation.

Penn. Stat. \ 43.107 (2014). 
Penn. Stat. \ 43.1301.207(c) (2014).

Polaski, S. (2004). Mexican employment, productivity and income a decade after NAFTA. Retrieved from http://carnegieendowment.org/2004/02/25/ mexican-employment-productivity-and-incomedecade-after-nafta

Quadagno, J. (1995). The color of welfare: How racism undermined the war on poverty. New York: Oxford University Press.

Rhode Island Gen. Laws \28-3-14(b) (2014).

Robinson, E., Nguyen, H. T., Isom, S., Quandt, S. A., Grzywacz, J. G., Chen, H., \& Arcury, T. A. (2011). Wages, wage violations, and pesticide safety experienced by migrant farmworkers in North Carolina. New Solutions, 21(2), 251-268. http://new.sagepub.com/content/21/2/251. abstract

Rowe, S. (2015, July 16). Washington Supreme Court rules farmworkers must be paid separately for resk breaks. Retrieved from http://www.goskagit.com/ all access/washington-supreme-court-rulesfarmworkers-must-be-paid-separately-for/article 3b522eae-2be2-11e5-85f7-8f932434e89e.html

Sbicca, J. (2015). Food labor, economic inequality, and the imperfect politics of process in the alternative food movement. Agriculture and Human Values, 32(4), 675-687. http://dx.doi.org/10.1007/s10460015-9582-2

Southern Poverty Law Center. (2013). Close to slavery: Guestworker programs in the United States (2013 Ed.). Retrieved from https://www.splcenter.org/ 20130218/close-slavery-guestworker-programsunited-states

Tichenor, D. J. (2002). Dividing lines: The politics of immigration control in America. Princeton, New Jersey: Princeton University Press.

United Farm Workers. (n.d.). The 1965-1970 Delano grape strike and boycott. Retrieved July 30, 2013, from http://www.ufw.org/ board.php?mode= view\&b code $=c c$ his research\&b no $=10482$

United Farmworkers \& Bon Appetit Management Company Foundation. (2011). Inventory of farmworker issues and protections in the United States. Retrieved from http://www.ufw.org/pdf/farmworker inventory 0401 2011.pdf

U.S. Department of Agriculture [USDA]. (2009). Wages and hours worked: Minimum wage and overtime pay. Retrieved November 13, 2014, from http://www.dol.gov/compliance/guide/minwage. htm\#who

USDA. (2014). 2012 Census of Agriculture: Race/ethnicity/gender profile. Retrieved March 25, 2015, from http://www.agcensus.usda.gov/Publica tions/2012/Online Resources/Race, Ethnicity and_Gender_Profiles/cpd99000.pdf

U.S. Department of Labor [DOL]. (n.d.). Breaks and meal periods. Retrieved November 14, 2014, from http://www.dol.gov/dol/topic/workhours/breaks. $\underline{\mathrm{htm}}$

U.S. DOL. (2004). The National Agricultural Workers Survey, Chapter 5: Farm job characteristics.

Retrieved December 5, 2014, from http://www.doleta.gov/agworker/report9/chapter $\underline{5 . \mathrm{cfm}}$

U.S. DOL. (2009). Work authorization for non-U.S. citizens: Temporary agricultural workers (H-2A Visas). Retrieved July 23, 2013, from http://www.dol.gov/compliance/guide/taw.htm

U.S. DOL, Bureau of Labor Statistics. (2012, October 25). Workplace injury and illness summary [News release]. Retrieved July 29, 2013; archived at https://web.archive.org/web/20130801084354/ http://www.bls.gov/news.release/osh.nr0.htm

U.S. DOL, Wage and Hour Division. (n.d.-a). Overtime pay. Retrieved November 13, 2014, from http://www.dol.gov/whd/overtime_pay.htm

U.S. DOL, Wage and Hour Division. (n.d.-b). Minimum wage laws in the states-January 1, 2013. Retrieved August 25, 2013; archived at http://web.archive. org/web/20130911041135/http://www.dol.gov/ whd/minwage/america.htm

U.S. DOL, Wage and Hour Division. (n.d.-c). Minimum length of meal period required under state law for adult employees in private sector, January 1, 2014. Retrieved November 10, 2014, from http://www.dol.gov/whd/state/meal2014.htm

U.S. DOL, Wage and Hour Division. (n.d.-d). Minimum paid rest period requirements under state law for adult employees in private sector, January 1, 2014. Retrieved November 10, 2014, from http://www.dol.gov/whd/state/rest2014.htm

U.S. DOL, Wage and Hour Division. (2008a). Fact sheet \#12: Agricultural employers under the Fair Labor Standards Act (FLSA). Retrieved from http://www.dol.gov/whd/regs/compliance/whdfs 12.pdf 
U.S. DOL, Wage and Hour Division. (2008b). Fact sheet \#22: Hours worked under the Fair Labor Standards Act (FLSA). Retrieved March 19, 2015, from http://www.dol.gov/whd/regs/compliance/whdfs 22.htm

Villarejo, D., Lighthall, D., Williams, D. III, Souter, A., Mines, R., Bade, B.,...McCurdy S. A. (2000). Suffering in silence: A report on the health of California's agricultural workers. Los Angeles: California Institute for Rural Studies \& The California Endowment. Retrieved from http://www.donvillarejo.com/exec $\underline{\text { sum/suffering in silence research brief.pdf }}$
Washington State Farmworker Housing Trust. (2008). A sustainable bounty: Investing in our agricultural future. Retrieved from http://www.orfh.org/downloads/ SustainableBounty.pdf

Whitaker, E. A., Herian, M. N., Larimer, C. W., \& Lang, M. (2012). The determinants of policy introduction and bill adoption: Examining minimum wage increases in the American states, 1997-2006. Policy Studies Journal, 40(4), 626-649. http://dx.doi.org/ 10.1111/j.1541-0072.2012.00467.x

Wisc. Ann. Stat. \103.935(2) (2014). 


\section{Appendix A. List of Terms Excluded from Data Collection}

- criminal code

- wage theft and wage boards

- unemployment insurance

- workers compensation

- specific sectors of irrelevant employment or laborers (e.g., disabled, school teachers, domestic workers, etc.)

- child labor and/or labor done by minors (even if relevant to agriculture)

- power of commissioners and/or power of regulators

- standards applicable only to public employees or government personnel

- standards applicable only to meat inspectors

- record-keeping requirements

- enforcement of labor laws

- tipped employees

- deductions for room, board, etc.

- flexible work plans

- requirements for posting anything in workplaces

- preemption and local power 